\title{
Effect of Different Rhizobial Strains on Growth and Yield of Soybean [Glycine max (L.) Merrill]
}

\author{
Mukesh Kumar Regar ${ }^{*}$, R.H. Meena, Gajanand Jat and S.L. Mundra \\ Department of Agricultural Chemistry and Soil Science, Rajasthan College of Agriculture, \\ Maharana Pratap University of Agriculture and Technology, Udaipur, Rajasthan, 313001, India \\ *Corresponding author
}

\section{A B S T R A C T}

Keywords

Rhizobial strains, Soybean, Growth, Yield, Net returns.

Article Info

Accepted:

26 September 2017

Available Online:

10 November 2017
A field experiment was conducted at Instructional Farm, Rajasthan College of Agriculture, Udaipur (Rajasthan) in kharif 2016 to assess the effect of different rhizobial strains on growth, yield and net returns of soybean. The experiment was laid out in randomized block design with four replications. The experiment comprised with nine treatments of different rhizobial strains to the soybean and one treatment should be uninoculated. The results revealed that inoculation with different Rhizobial isolates have significant influence on growth parameters, yield \& yield attributes and net returns of soybean.

\section{Introduction}

Soybean (Glycine max L.) is one of the major grain legume crops, whose production is getting popularized and adopted in the region of Southern Rajasthan. The governmental and non-governmental bodies also undertaken for the purpose of making to aware of the importance of soybean to small land holding farmers not only as a crop for improving their economic status but also as an important high protein food. India ranks fifth in soybean production in the world. Soybean production is mainly confined to Madhya Pradesh (also known as bowl of soybean in India), Maharashtra, Rajasthan, Andhra Pradesh, Karnataka, Uttar Pradesh and Chhattisgarh (Pawar et. al, 2011). In Rajasthan, soybean is mainly cultivated in the south eastern part of the state covering Kota, Bundi, Baran and Jhalawar districts which are known as Haroti region while it is grown in patches in some other districts like Sawai Madhopur, Bhilwara, Chittorgarh, Rajsamand, Dungarpur, Banswara and Udaipur (SOPA, 2001). Total area of soybean in Rajasthan in the year 2015-16 was 11.04 lakh ha with production of 7.86 lakh MT (Anonymous, 2015-16).

It is a source of edible oil having 20-25 percent and protein 42-45 percent content (Alam et al., 2009). Soybean is a promising pulse crop proposed for the alleviation of the acute shortage of protein and oil worldwide (Mahamood et al., 2009). It used as a good 
source of unsaturated fatty acids, minerals $(\mathrm{Ca}$ and $\mathrm{P}$ ) and vitamins $\mathrm{A}, \mathrm{B}, \mathrm{C}$ and D (Alam et al., 2009). Soybean protein contributes all eight amino acids in the amount needed for human health; hence it is called meal of the field (Rathore, 2000). It is therefore, highly desirable in human diet and animal (Haq et al., 2002).

Soybean has a unique importance in the Indian agricultural economy due to great shortage of edible oil in the country. Since, past few years, the consumption of oil has been increasing steadily as a result of rise in population and living standard of people, the basic question before the scientist is to develop a concrete strategy that permits selfreliance in edible oils (Meghvansi et al., 2006). Soybean oil is the world most widely used edible oil, as it is low in cholesterol, with a natural taste and nearly imperceptible odour, which makes it the ultimate choice of vegetable oil for domestic and industrial food processing units (Mpepereki et al., 2000).

Nitrogen is a limiting nutrient for growth and yield of soybean, rhizobia have a direct role to play in its supply to the growing plants (Kanimozhi and Panneerselvam 2010). Bradyrhizobium japonicum capable of forming root nodules on soybean. The ability to form nodules has been found to be highly host specific for different species of rhizobia (Jordan, 1982).

Better $\mathrm{N}_{2}$ fixation can be achieved by selecting superior Rhizobia. However, selection of these Rhizobia would need to take into consideration not only their $\mathrm{N}_{2}$-fixing capacity, but also competitive ability against native Rhizobia which are frequently ineffective in $\mathrm{N}_{2}$ fixation have to out compete with native Rhizobia and occupy a significant proportion of the nodules. The subject of symbiotic effectiveness and competitiveness of Rhizobia in Indian context assumes more significance and has attracted a lot of Indian workers (Shivananda et al., 2000; Appunu and Dhar 2006 and Appunu et al., 2008). However, in Rajasthan, most of the Rhizobial research has been confined to the tree legumes (Srivastava and Prabhakaran, 1999) while little attention has been paid to the studies on Rhizobia of soybean despite being an important oil yielding crop. As a consequence, symbiotic potential of the Rhizobia autochthonous to different soybean growing regions of Rajasthan is still unexploited.

\section{Materials and Methods}

The experiment was conducted at Instructional Farm, Rajasthan College of Agriculture, Udaipur (Rajasthan) in kharif 2016 on sandy clay loam soil which is slightly alkaline in nature consisted of 9 treatments of different rhizobial strains, viz., SB-22 $\left(\mathrm{T}_{2}\right)$, SB-272 $\left(\mathrm{T}_{3}\right), \mathrm{SB}-31\left(\mathrm{~T}_{4}\right), \mathrm{SB}-431\left(\mathrm{~T}_{5}\right), \mathrm{SB}-$ $401\left(\mathrm{~T}_{6}\right), \mathrm{SB}-441\left(\mathrm{~T}_{7}\right), \mathrm{SB}-442\left(\mathrm{~T}_{8}\right), \mathrm{SB}-481$ $\left(\mathrm{T}_{9}\right)$ and $\mathrm{SB}-402\left(\mathrm{~T}_{10}\right)$, respectively and control $\left(\mathrm{T}_{1}\right)$. These treatments were evaluated under randomized block design (RBD) with four replications. Soybean cultivar (JS - 9560) was taken as test crop.

\section{Results and Discussion}

\section{Effect of inoculation on plant growth}

Data presented in Table 1 revealed that inoculation of seed with different Rhizobium strains significantly increased in different growth parameter, viz. plant height, shoot dry weight, dry matter accumulation, fresh root weight, dry root weight, number of nodule at 60 DAS and nodule dry weight was increased when seed was inoculated with different Rhizobial strains. The highest plant height was observed in inoculation with SB - 401 $(110.50 \mathrm{~cm})$, maximum shoot dry weight $\left(21.60 \mathrm{~g}\right.$ plant $\left.^{-1}\right)$ was observed with 
inoculation of SB-401, maximum dry matter accumulation (10.65 $\left.\mathrm{g} \mathrm{plant}^{-1}\right)$ was observed of the plants which were inoculated with SB401 strain $\left(\mathrm{T}_{6}\right)$ which was followed by SB$402\left(\mathrm{~T}_{10}\right)$, highest fresh root weight $(18.24 \mathrm{~g}$ plant $^{-1}$ ) was recorded with SB- 401 isolate, inoculation with SB- $401 \quad\left(\mathrm{~T}_{6}\right)$ produced highest root dry weight $\left(9.45 \mathrm{~g} \mathrm{plant}^{-1}\right)$, highest number of nodule (37.88) was observed with plants raised from seed inoculated with the soybean isolate SB- 401 $\left(\mathrm{T}_{6}\right)$ however, it was found statistically at par with SB-272( $\left.\mathrm{T}_{3}\right), \mathrm{SB}-31\left(\mathrm{~T}_{4}\right), \mathrm{SB}-431\left(\mathrm{~T}_{5}\right)$, SB441 $\left(\mathrm{T}_{7}\right), \mathrm{SB}-442\left(\mathrm{~T}_{8}\right), \mathrm{SB}-481\left(\mathrm{~T}_{9}\right)$ and SB-402 $\left(\mathrm{T}_{10}\right)$ number of nodules per plants was increased 35.28 and 32.14 percent per plant under the seed inoculated with SB- $401\left(\mathrm{~T}_{6}\right)$ and SB-402 $\left(\mathrm{T}_{10}\right)$, highest nodule weight (1.69 g plant $\left.^{-1}\right)$ was recorded with SB- 401 $\left(\mathrm{T}_{6}\right)$ respectively over uninoculated treatment. The results of the present study that inoculation of different Rhizobial strains has been found to be providing higher growth of plant with those reported by Seed inoculation with different Rhizobium strains significantly increased growth attributes viz., plant height, shoot dry weight, fresh root weight, root dry weight and number of nodules plant ${ }^{-1}$. The significantly higher growth parameters were associated with Rhizobium isolate SB-401.

The variation in plant height might be due to the inoculation of effective Rhizobial strain. These results are in agreement with the findings of Solaiman (1999). Gupta et al., (2005), they mentioned that plant height can also be increased significantly by inoculation of effective soybean rhizobial strains. These findings are confirming the observations of earlier workers Khan et al., (2014), Nyoki and Ndakidemi (2014). Seeds inoculated by different Rhizobium strains showed significantly higher nodulation, fresh root weight and root dry weight over control. Nodulation might be due to the effective symbiosis between soybean plants and rhizobial strains. Higher number of nodules may be increased by inoculation with effective rhizobial strains. Similar findings were also reported by Alagawadi et al., (1993) and Devi and Gupta (1996).

\section{Effect of Inoculation on yield \& yield attributes}

As evident from the results (Table 2) inoculation of different rhizobial strains showed significant difference in number of pod plant ${ }^{-1}$ and number of seed $\operatorname{pod}^{-1}$. The maximum number of pod plant ${ }^{-1}$ and number of seed $\operatorname{pod}^{-1}$ was 41.25 and 3.26 obtained from the plant inoculated with strain SB-401. The minimum number of pod plant $^{-1}$ and number of seed pod $^{-1}$ was 30.50 and 1.50 counted from control.

Similar trendes was found in test weight (1000 grains weight) and harvest index. Highest test weight and harvest index was found in SB-401 $133.50 \mathrm{gm}$ and $36.70 \%$ due to inoculation of seed with different Rhizobial strains but harvest index is statistically found non-significant.

Different rhizobial strains inoculation significantly influenced the seed, straw and biological yield of soybean. The highest seed, straw and biological yield was 1776.25, 3110.98 and $4887.23 \mathrm{~kg} / \mathrm{ha}$ recorded from the plant inoculated with strain SB-401. The lowest seed, straw and biological yield was 1280,2295 and $3575 \mathrm{~kg} / \mathrm{ha}$ recorded from uninoculated treatment respectively (Figure $1)$.

Similar results also obtained due to the fact that Rhizobium inoculation increased the root nodulation, better root development and more nutrient availability, resulting in vigorous plant growth and dry matter production which resulted in better flowering, fruiting and pod formation and ultimately seed yield. 
Table.1 Effect of different Rhizobial strains on different growth parameters

\begin{tabular}{|c|c|c|c|c|c|c|c|}
\hline Treatments & $\begin{array}{l}\text { Plant height } \\
\text { (cm) }\end{array}$ & $\begin{array}{l}\text { Shoot dry } \\
\text { weight }^{-1} \\
\left.\text { (g plant }^{-1}\right)\end{array}$ & $\begin{array}{c}\text { Dry matter } \\
\text { accumulation } \\
\left(\mathrm{g} \mathrm{plant}^{-1}\right)\end{array}$ & $\begin{array}{c}\text { Fresh root } \\
\text { weight }^{-1} \\
\left.\text { (g plant }^{-1}\right)\end{array}$ & $\begin{array}{c}\text { Dry root } \\
\text { weight }^{-1} \\
\left.\text { (g plant }^{-1}\right)\end{array}$ & $\begin{array}{c}\text { Number of } \\
\text { nodule at } 60 \\
\text { DAS }\end{array}$ & $\begin{array}{c}\text { Nodule } \\
\text { weight } \\
\left.\text { (g plant }^{-1}\right)\end{array}$ \\
\hline T1- Control & 83.11 & 12.50 & 5.98 & 9.75 & 5.06 & 28.00 & 1.09 \\
\hline T2- SB- 22 & 96.75 & 16.75 & 7.58 & 14.25 & 7.75 & 33.75 & 1.21 \\
\hline T3- SB- 272 & 99.25 & 16.75 & 7.68 & 15.00 & 7.75 & 34.75 & 1.25 \\
\hline T4-SB- 31 & 100.50 & 19.50 & 7.48 & 15.25 & 7.83 & 36.00 & 1.29 \\
\hline T5- SB- 431 & 102.50 & 14.50 & 7.98 & 17.50 & 9.05 & 36.75 & 1.33 \\
\hline T6- SB- 401 & 110.50 & 21.60 & 10.65 & 18.24 & 9.45 & 37.88 & 1.69 \\
\hline T7- SB- 441 & 106.75 & 18.00 & 8.15 & 17.01 & 8.50 & 36.75 & 1.32 \\
\hline T8- SB- 442 & 101.75 & 18.75 & 8.99 & 16.50 & 8.25 & 35.25 & 1.44 \\
\hline T9- SB- 481 & 98.25 & 20.25 & 9.00 & 15.00 & 7.75 & 36.75 & 1.52 \\
\hline T10- SB- 402 & 103.25 & 18.50 & 9.53 & 16.00 & 8.75 & 37.00 & 1.48 \\
\hline SEm \pm & 3.63 & 0.29 & 0.17 & 0.33 & 0.15 & 1.22 & 0.02 \\
\hline $\mathrm{CD}(\mathrm{P}=0.05)$ & 10.525 & 0.845 & 0.492 & 0.950 & 0.437 & 3.539 & 0.071 \\
\hline
\end{tabular}

Table.2 Effect of different Rhizobial strains on yield attributes

\begin{tabular}{|c|c|c|c|c|}
\hline Treatments & $\begin{array}{c}\text { Number of pod } \\
\text { plant }^{-1}\end{array}$ & $\begin{array}{c}\text { Number of seed } \\
\text { pod }^{-1}\end{array}$ & $\begin{array}{c}\text { Test weight } \\
(\mathbf{g m})\end{array}$ & $\begin{array}{c}\text { Harvest index } \\
(\mathbf{\%})\end{array}$ \\
\hline T1- Control & 30.50 & 1.50 & 104.50 & 35.80 \\
\hline T2- SB- 22 & 36.50 & 2.50 & 121.00 & 35.42 \\
\hline T3- SB- 272 & 38.50 & 2.25 & 125.75 & 35.54 \\
\hline T4- SB- 31 & 38.25 & 2.75 & 130.00 & 35.72 \\
\hline T5- SB- 431 & 39.75 & 2.25 & 127.75 & 34.36 \\
\hline T6- SB- 401 & 41.25 & 3.26 & 133.50 & 36.47 \\
\hline T7- SB- 441 & 40.75 & 2.50 & 126.75 & 35.41 \\
\hline T8- SB- 442 & 39.00 & 2.00 & 128.50 & 34.24 \\
\hline T9- SB- 481 & 37.55 & 2.75 & 129.00 & 34.86 \\
\hline T10- SB- 402 & 37.25 & 2.75 & 130.25 & 35.41 \\
\hline SEm \pm & 1.49 & 0.08 & 1.83 & 0.81 \\
\hline CD $(\mathbf{P = 0 . 0 5 )}$ & 4.33 & 0.24 & 5.29 & NS \\
\hline
\end{tabular}

Table.3 Effect of different Rhizobial strains on gross returns and net returns

\begin{tabular}{|c|c|c|}
\hline Treatments & Gross return $\left.^{(} \mathbf{~ h a}^{-1}\right)$ & Net return $\mathbf{( h a}^{-1}$ ) \\
\hline T1- Control & 52832.50 & 41312.50 \\
\hline T2- SB- 22 & 65590.00 & 51690.00 \\
\hline T3- SB- 272 & 66073.00 & 52173.00 \\
\hline T4- SB- 31 & 67935.00 & 54035.00 \\
\hline T5- SB- 431 & 65441.78 & 51541.78 \\
\hline T6- SB- 401 & 73057.18 & 59157.18 \\
\hline T7- SB- 441 & 69447.76 & 55547.76 \\
\hline T8- SB- 442 & 66779.48 & 52879.48 \\
\hline T9- SB- 481 & 67950.00 & 54050.00 \\
\hline T10- SB- 402 & 69434.49 & 55534.49 \\
\hline SEm \pm & 2371.04 & 2371.04 \\
\hline CD $(\mathbf{P}=\mathbf{0 . 0 5})$ & 6880.11 & 6880.11 \\
\hline
\end{tabular}


Fig.1 Effect of different rhizobial strains on yield of crop

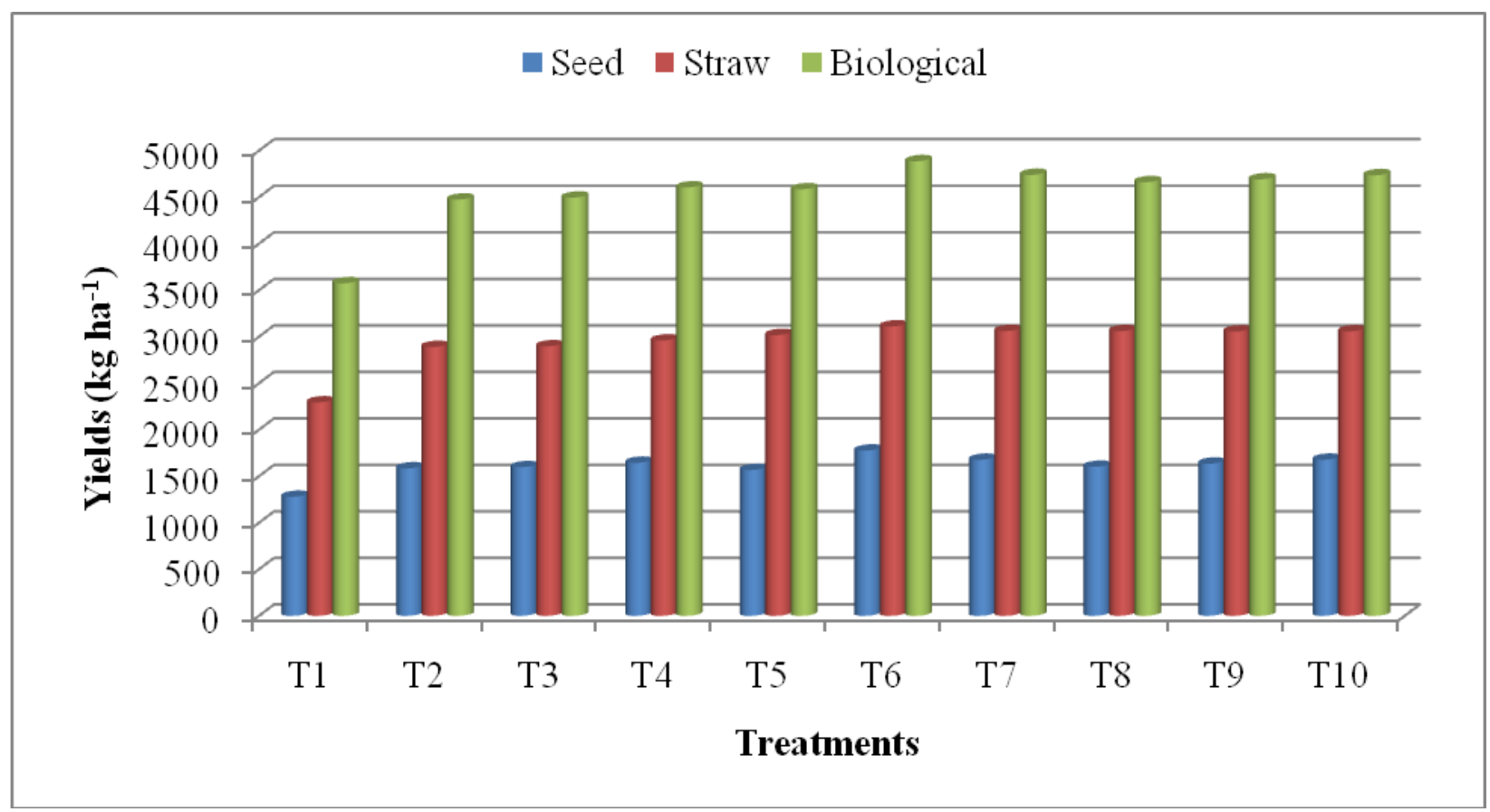

The substantial increase in yield observed in the Rhizobium inoculated seeds may be due to the nitrogen fixation potential of soybean. Similar results were reported by Kumawat, et al., (2000) and Patra et al., (2012).

These results could be explained by the reported symbiosis efficiency between soybean and Bradyrhizobium japonicum (Abbasi et al., 2008). Increased nodulation and subsequent $\mathrm{N} 2$ fixation due to inoculation might have resulted in the measured increases in yield and yield components of soybean. In addition, increased NPK uptake may also be due to better availability of nutrients by Rhizobium inoculation may also contributed to increase soybean yield and yield components as significant positive correlations existed between these components. Increased soybean yields due to inoculation have also been reported by earlier many researchers. Egamberdiyeva et al., (2004) reported 48\% increase in soybean yield after inoculation in Uzbekistan while Okereke et al., (2001) in Nigeria found a significant increase in soybean seed yields after Bradyrhizobium inoculation varied between 14-108\% compared to the noninoculated treatment. Zhang et al., (2002) suggested that Bradyrhizobium japonicum improved seed yield of soybean largely due to increase in pod and seed number as observed in this study. Comparative assessment of the results of the field experiment indicated a significant improvement in nodulation, vegetative growth and seed yield of three soybean genotypes grown in Rajasthan, India (Meghvansi et al., 2010). The findings of this investigation confirm the observations of earlier workers, Tanwar (2003), Malik et al., (2006) and Abdalgani et al., (2014).

\section{Effect of Inoculation on net returns of soybean}

The data presented in Table 3 showed that seed inoculation of different Rhizobial strains give highest net returns. Highest net returns and gross returns was found with isolate SB401 (Rs. 59157.18 and $73057.18 \mathrm{ha}^{-1}$ ) as 
compared to control (Rs. 41312.50 and $52832.50 \mathrm{ha}^{-1}$ ) and other treatments. It is obvious that net returns and gross returns increased with increased in seed and straw yield in soybean crop.

\section{References}

Abbasi MK, Majeed A, Sadiq A, Khan SR (2008). Application of Bradyrhizobium japonicum and phosphorus fertilization improved growth, yield and nodulation of soybean in the sub-humid hilly region of Azad Jammu and Kashmir, Pakistan. Plant Production Science 58: 368-376.

Abdalgani, B., Boulila, F., Ahnia, H. and Rey, H. 2014. Cytisus villosus from northeastern Algeria is nodulated by genetically diverse bradyrhizobium strains. Springer Iinternational Publishing Switzerland, 10.1007/s10482.

Alagawadi, A.R., Siddaramegowda, T.K. and Habib, A.F. 1993. Groundnut crop response to Rhizobium inoculation. Madras Agriculture Journal, 70(10): 635-637.

Alam, M. A., Siddiqua, A., Chowdhury, M. A. and Pradhan, M. Y. 2009. Nodulation, yield and quality of soybean as influenced by integrated nutrient management. Bangladesh Agriculture University 7(2): 229-234

Anonymous, 2015-16. Directorate of Agriculture, Pant Krishi Bhawan, Govt. of Rajasthan.

Appunu, C. and Dhar, B., 2006. Differential symbiotic response of Bradyrhizobium japonicum phage-typed strains with soybean cultivars. Journal of Microbiology, 44: (3): 363-368.

Appunu, C., Sen, D., Singh, M.K. and Dhar, B. 2008. Variation in symbiotic performance of Bradyrhizobium japonicum strains and soybean cultivars under field conditions. Journal of Central European Agriculture, 9: 185-190.

Devi, S. and Gupta, P. 1996. Effect of four green manures against Heterodera cajani on pigeon pea sown with or without Rhizobium seed treatment. Indian Journal of Micology and Plant Pathology, 25(3):254-256.

Egamberdiyeva, D., Qarshieva, D. and Davranov,
K. 2004. Growth and yield of soybean varieties inoculated with Bradirhizobium spp in N-deficient calcareous soils. Biology of Fertile Soils (40) : 144-146.

Gupta, S.B., Choudhary, T., Tedia, K. and Katre, R.K. 2005. Isolation and selection of effective Rhizobium isolates for soybean (Glycine $\max$ L.) growers of Chhattisgarh. Indian Journal of Agriculture Sciences. 75(8):507-509.

Haq, I., Hussain, I., Khan, A.R., Sajid, M. and Khan, S. 2002. Soybean genotypic response in Abbottabad. Asian Journal of Plant Science, 1: 418-419.

Jordan, D.C. 1982. Genetic diversity in Bradyrhizobium japonicum and a proposal for Bradyrhizobium elkanii species. International Journal of Systemics Bacteriol. 32: 136-139.

Kanimozhi, K. and Panneerselvam 2010. Studies on isolation and nitrogen fixation ability of Azospirillum spp. isolated from Thanjavur district. Der Chemica Sinica, 1 (3): 138-145.

Khan, K., Pankaj, U., Verma, S. K., Gupta, A. K., Singh, R. P. and Verma, R. K. 2014. Bioinoculants and vermicompost influence on yield, quality of Andrographis Paniculata, and soil properties. Industrial Crops and Products, 70: 404-409.

Kumawat, N. Kumar, R.and Sharma, O. P. 2002. Nutrient Uptake and Yield of Mungbean Vigna radiata (L.) Wilczek as Influenced by Organic Manures, PSB and Phosphorus Fertilization, Environment \& Ecology 27 (4b): 125-129.

Mahamood, J. Abayomi, Y. A. and Aduloju, M. O. 2009. Comparative growth and grain yield responses of soybean genotypes to phosphorous fertilizer application. African Journal of Biotechnology, 8(6): 1030-1036.

Malik, A. M., Cheema, M. A., Khan, H. Z. and Wahid, M. A. 2006. Growth and Yield Response of Soybean to Seed Inoculation varying $\mathrm{P}$ Level. Journal of Agriculture Research, 44 (1): 47-56.

Meghvansi, M.K., Harwani, D., Prasad, K., Mahna, S.K., and Werner, D. 2010. Screening of efficient Bradyrhizobium japonicum strains for the improvement of soybean production. In: Bagyanarayana, G., Bhadraiah, B., Kunwar, I.K. (Eds.), 
Emerging Trends in Mycology, Plant Pathology and Microbial Biotechnology. B.S. Publications, Hyderabad, India, pp. 267-277.

Meghvansi, M.K., Prasad, K. and Mahna, S.K. 2006. Identification of $\mathrm{pH}$ tolerant Bradyrhizobium japonicum strains and their symbiotic effectiveness in soybean [Glycine max (L.) Merrill] in low nutrient soil. African Journal of Biotechnology, 4: 663666.

Mpepereki, S., Javaheri, F. and Davis, P. 2000. Soybean and Sustainable Agriculture: Promiscuous Soybean in Southern Africa. Field Crops Research, 63: $137-149$.

Nyoki, D. and Ndakidemi, P.A. 2014. Effect of phosphorus and Bradyrhizobium japonicum on growth and chlorophyll content of cowpea (Vigna unguiculata (L.) Walp). American Journal of Experimental Agriculture, 4(10): 1120-1136.

Okereke, G.U., Onochie, C. and Onyeagba, E. 2001. Effectiveness of foreign bradyrhizobia strains in enhancing nodulation, dry matter and seed yield of soybean (Glycine $\max$ L.) cultivars in Nigeria. Biology and Fertility of Soils, 33: 3-9.

Patra, R.K., Pant, L.M. and Pardhan, K.2012. Response of Soybean to Inoculation with Rhizobial Strains : Effect on Growth, Yield, N Uptake and Soil N Status. World Journal of Agricultural Sciences, 8 (1): 51-54.

Pawar, R.S. Wagh, V.M. Panaskar, D.B. Adaskar, V.A. and Pawar, P.R. 2011. A Case Study of Soybean Crop Production, Installed Capacity and Utilized Capacity of Oil Plants in Nanded District, Maharashtra,
India. Advances in Applied Science Research, 2 (2): 342-350.

Rathore, Y.S. 2000. Integrated nutrient management in soybean. M.Sc. Thesis. Jawaharlal Nehru Krishi Vishwa Vidhyalaya, Jabalpur, India.

Shivananda, T.N., Rudraswamy, P., Viswanath, R.S., Viswanath, D.P. and Siddaramappa, R. 2000. Field evaluation of soybean (Glycine $\max$ L.) genotypes for root nodulation, biomass accumulation and seed yield in different soils. Indian Journal of Agricultural Sciences, 70 (8): 534-535.

Solaiman, A.R.M. 1999. Nitrogenase activity, yield and yield contributing characters of chickpea as influenced by Rhizobium inoculant in presence and absence of nitrogen. Bangladesh Journal of Science Technology 1(1):141-144.

SOPA, 2001. Soybean Oil and Processors Association, Indore (M.P.).

Srivastava, K.K. and Prabhakaran, R. 1999. Effect of nodulation on biomass of some arid zone tree species. Indian Forester, 125: 12651268.

Tanwar, S. P. S. and Shaktawat, M. S. 2003. Influence of phosphorus sources, levels and solubilizers on yield, quality and nutrient uptake of soybean (Glycine max)-wheat (Triticum aestivum) cropping system in southern Rajasthan. Indian Journal of Agricultural Sciences, 73: 3-7.

Zhang, J. and Davies W.J. 2002 "Root signals and the regulations of growth and development of plants in drying soil". Annual Reveal of Plant Physiology and Molecular Biology 42, 1991, pp. 55-76.

\section{How to cite this article:}

Mukesh Kumar Regar, R.H. Meena, Gajanand Jat and Mundra, S.L. 2017. Effect of Different Rhizobial Strains on Growth and Yield of Soybean [Glycine max (L.) Merrill]. Int.J.Curr.Microbiol.App.Sci. 6(11): 3653-3659. doi: https://doi.org/10.20546/ijcmas.2017.611.427 